\title{
PENERAPAN PEMBELAJARAN TEAM GAMES TOURNAMENT UNTUK MENINGKATKAN MINAT BELAJAR MATEMATIKA DI KELAS VII BMP NEGERI 2 PANGKALAN KERINCI
}

\author{
Romita Dasra \\ SMP Negeri 2 Pangkalan Kerinci \\ Email: romita.dasra@gmail.com
}

\begin{abstract}
Abstrak. Penelitian ini bertujuan untuk meningkatkan proses pembelajaran dan meningkatkan minat belajar dengan menerapkan pembelajaran Turnamen Teams Games. Subyek penelitian ini adalah siswa kelas VII B SMP Negeri 2 Pangkalan Kerinci pada semester genap tahun akademik 2016/2017, yang berjumlah 28 siswa, terdiri dari 13 anak laki-laki dan 15 perempuan. Penelitian ini terdiri dari tiga siklus, setiap siklus memiliki empat tahap, yaitu perencanaan, pelaksanaan, pengamatan, dan refleksi. Di akhir setiap siklus, gim akan diimplementasikan. Pengumpulan data dilakukan dengan observasi. Hal ini dapat dilihat dari hasil presentase minat belajar pada siklus I hanya sebesar 60,71\% meningkat $81,24 \%$ pada siklus II dan 87,49\% pada siklus III. Hasil penelitian ini menunjukkan bahwa penerapan pembelajaran Teams Games Tournament dapat meningkatkan minat belajar siswa kelas VII B SMP Negeri 2 Pangkalan Kerinci pada semester genap tahun akademik 2016/2017.
\end{abstract}

Kata Kunci. Teams Games Tournament, Learning Interest.

\section{PENDAHULUAN}

Matematika merupakan bagian dari ilmu pengetahuan yang turut memberikan sumbangan signifikan terhadap perkembangan ilmu pengetahuan dan sekaligus pembangunan Sumber Daya Manusia (SDM). Begitu pentingnya peranan matematika sehingga pada setiap jenjang pendidikan mulai dari prasekolah, pendidikan dasar, pendidikan menengah hingga pendidikan tinggi, matematika selalu diajarkan dengan menyesuaikan pada perkembangan aspek kognitif, afektif dan psikomotorik peserta didik. Matematika diajarkan karena setiap individu perlu memiliki penguasaan akan kecakapan matematika (mathematical literacy) pada tingkat tertentu.

Trend dunia pendidikan abad 21 berorientasi kepada pengembangan potensi manusia. Jika manusia menggunakan potensinya akan mampu berbuat walaupun sebelumnya dia tidak mampu berbuat. Mengingat begitu pentingnya potensi manusia, sebagai guru kita tentu berupaya untuk menggali potensi siswa, salah satunya adalah minat belajar. Menurut Daryanto (2012:8) minat adalah suatu sifat yang relatif menetap pada diri seseorang. Hal ini dapatlah dimengerti bahwa kecendrungan seseorang untuk melakukan sesuatu disebabkan karena ia berminat untuk melakukannya. Artinya, adanya minat siswa ditandai dengan adanya kecenderungan kemauan dari dalam dirinya terhadap hal-lal lain yang ada di lingkungannya seperti ketertarikan terhadap benda, orang, atau kegiatan yang sedang dilakukannya.

Keberhasilan pembelajaran pada ranah kognitif dan keterampilan dipengaruhi oleh kondisi afektif peserta didik. Menurut Lucy (2009:11) minat yang positif akan membentuk sikap yang positif terhadap pembelajaran. Kalau sudah mempunyai sikap yang positif siswa akan mempunyai ketertarikan terhadap pelajaran. Inilah sebabnya mengapa siswa harus mempunyai minat belajar. Jika minat belajar ada dalam dirinya maka ia akan bersemangat menerima pelajaran yang disajikan. Peserta didik yang memiliki minat belajar dan sikap positif akan merasa senang mempelajari mata pelajaran tertentu. Jika peserta didik bisa berfikir positif terhadap pembelajaran Matematika akan mendapatkan hasil yang lebih baik. Dengan berbekal kesadaran terhadap kegunaan Matematika membuat peserta didik akan lebih mudah menerima pelajaran.

Kurangnya minat siswa dalam proses pembelajaran Matematika disebabkan oleh beberapa faktor baik dari diri siswa maupun dari cara guru mengajarkan materi pelajaran. Guru kreatif akan mampu membangkitkan minat belajar siswa. Menurut Marno (2014:84) dalam membangkitkan perhatian dan minat siswa ada beberapa cara yang dapat digunakan guru, salah satunya adalah variasi pola interaksi. Pendapat ini memberi makna bahwa guru dapat menarik perhatian siswa, dengan menggunakan variasi gaya mengajar yang sesuai dan tepat dengan materi pelajaran. Supriyadi (2015:130) menyatakan bahwa pola interaksi yang monoton antara guru dan siswa (GS), misalnya guru menerangkan-siswa mendengarkan, atau guru bertanya-siswa menjawab, biasanya tidak berhasil memikat perhatian siswa untuk waktu yang lama. Model yang bervariasi akan sangat membantu siswa dalam mencapai tujuan pembelajaran. Jika model pembelajaran kurang menarik alias monoton, akan 
berpengaruh yang tidak baik bagi semangat belajar siswa. Siswa bisa malas belajar, bosan, mengantuk dan akibatnya siswa tidak berhasil dalam menguasai materi pelajaran.

Penerapan model pembelajaran Matematika harus sesuai dengan pembelajaran abad 21. Untuk menghadapi tantangan masa depan, minimal ada tiga aspek yang harus diperhatikan yaitu penguatan pendidikan karakter, kemampuan literasi, kemampuan memecahkan masalah komplek yaitu dengan cara berkolaborasi (collaboration), kreativitas (creativity), berfikir kritis (critical thingking), dan dikomunikasikan (communication) yang dikenal dengan istilah $4 C$.

Untuk mengembangkan kemampuan literasi siswa dapat mencari informasi tentang materi pelajaran dari berbagai sumber. Siswa dapat membaca literatur, ditugaskan browsing di internet, atau menggali pengetahuan dari buku siswa. Ada keuntungan yang diperoleh dengan mengembangkan literasi. Siswa akan mendapatkan pembelajaran yang lebih jika dibandingkan dengan menerima informasi dari guru. Ilmu yang diperoleh sendiri dari membaca akan bertahan lebih lama. Selain itu siswa dapat menyambungkan pengetahuan yang sudah dimilikinya dengan ilmu yang dipelajari sekarang.

Dengan adanya pembelajaran kooperatif siswa yang berfikir lambat atau yang mempunyai inteligensi rendah tetap mampu mengikuti kegiatan-kegiatan yang sedang dilaksanakan dan siswa yang mempunyai inteligensi tinggi tidak memonopoli kegiatan (Fathurrohman, 2016:203). Agar pembelajaran terlaksana dengan baik, siswa harus diberi pengertian bahwa setiap anggota kelompok harus saling berbagi untuk menyelesaikan tugas.

Pembelajaran Teams Games Tournament merupakan pembelajaran alternatif untuk meningkatkan minat belajar dengan cara berkolaborasi. Penggunaan soal dirancang sedemikian rupa dalam bentuk permainan sehingga siswa berminat mengikuti pembelajaran. Dalam TGT, siswa memainkan permainan akademik dengan anggota-anggota kelompok lain untuk memperoleh tambahan poin pada skor kelompok mereka. Permainan itu dimainkan pada meja-meja turnamen. Setiap meja turnamen dapat diisi oleh wakil-wakil kelompok yang berbeda, namun yang memiliki kemampuan setara. Permainan itu disusun dari pertanyaan-pertanyaan yang relevan dengan pelajaran yang dirancang untuk menguji pengetahuan yang diperoleh siswa dari penyampaian materi pelajaran di kelas dan kegiatan-kegiatan kelompok berupa kartu pertanyaan. Tiap-tiap siswa akan mengambil sebuah kartu yang diberi angka dan berusaha untuk menjawab pertanyaan yang sesuai dengan angka tersebut.
Turnamen ini memungkinkan siswa menyumbang skor maksimal bagi kelompoknya bila mereka berusaha dengan maksimal.

Dalam pembelajaran Teams Games Tournament siswa didorong bekerjasama dalam tim. Mereka saling membantu melakukan kegiatan akademis dan saling mengatasi masalah yang mereka hadapi dalam pembelajaran sehingga mereka saling mengerti dan memahami pelajaran tersebut. Adapun langkah-langkah pembelajarannya adalah sebagai berikut:

1. Guru menyampaikan materi dalam tahap presentasi kelas (class precentation).

2. Guru menempatkan siswa dalam kelompok belajar yang beranggotakan 4 sampai 5 orang yang memiliki kemampuan, jenis kelamin, dan suku yang berbeda (teams).

3. Pelaksanaan permainan dalam bentuk pertandingan (games tournament).

Menurut Fathurrohman (2015:315), setiap meja turnamen siswa yang duduk di meja turnamen merupakan wakil dari kelompoknya.

4. Memberikan penghargaan kelompok (team recognition)

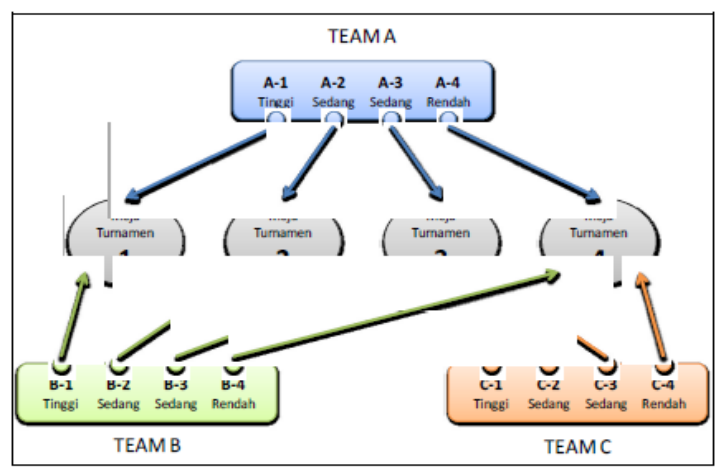

Gambar 1. Penempatan Siswa dalam Tim ke Meja Turnamen

Pelaksanaan games yang beranggota tiga orang menurut Fathurrohman (2015:321) dilakukan dengan prosedur sebagai berikut:

1. Peserta didik (3 orang dengan kemampuan setara) sudah duduk di meja turnamen

2. Peserta didik mencabut undian untuk menentukan pembaca soal, dan yang lain menjadi penantang I dan penantang II.

3. Pembaca soal menggocok kartu dan mengambil kartu yang teratas. Pembaca soal membaca soal sesuai nomor pada kartu dan mencoba menjawabnya. Pembaca soal hanya membacakan soal dan membuka kunci jawaban, tidak boleh ikut memberikan jawaban kepada peserta lain. Jika jawaban salah, tidak ada sanksi dan kartu 
dikembalikan. Jika benar kartu disimpan sebagai bukti skor.

4. Jika penantang I dan II memiliki jawaban berbeda, mereka dapat mengajukan jawaban secara bergantian.

5. Jika jawaban penantang salah, dia dikenakan pengembalian kartu jawaban yang benar (jika ada)

6. Selanjutnya siswa berganti posisi pemain berputar searah jarum jam agar setiap peserta dalam satu meja turnamen dapat berperan sebagai pembaca soal, penantang I dan penantang II.

Bagan dari putaran permainan dengan tiga siswa dalam satu meja turnamen adalah sebagai berikut:

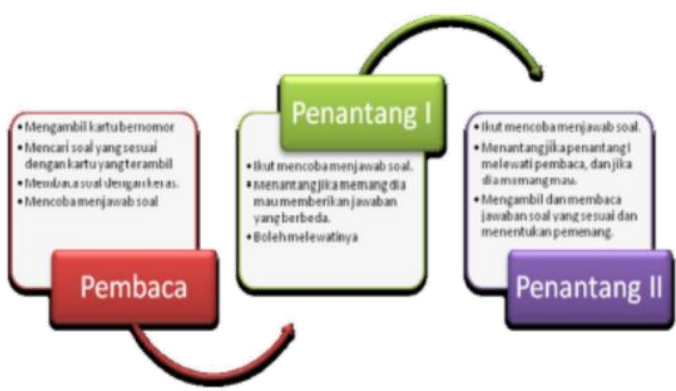

Gambar 2. Bagan dari Putaran Permainan dengan Tiga Siswa dalam Satu Meja Turnamen

Pemenang pada turnamen antar kelompok ditentukan dengan menghitung jumlah kartu yang dipegang oleh masing-masing kelompok. Skor yang diperoleh setiap peserta dalam permainan akademik dicatat pada lembar pencatat skor.

Tabel 1. Perhitungan Poin Permainan Untuk Tiga Pemain

\begin{tabular}{cc}
\hline $\begin{array}{c}\text { Pemain } \\
\text { dengan }\end{array}$ & $\begin{array}{c}\text { Poin Bila Jumlah } \\
\text { Kartu Yang Diperoleh }\end{array}$ \\
\hline Top scorer & 60 \\
Middle scorer & 40 \\
Low scorer & 20 \\
\hline
\end{tabular}

Skor kelompok diperoleh dengan menjumlahkan skor-skor yang diperoleh anggota suatu kelompok, kemudian dibagi banyaknya anggota kelompok tersebut. Untuk turnamen individu, peserta didik yang mendapat nilai tertinggi akan mendapatkan hadiah.

Dengan pembelajaran Teams Games Tournament maka guru dapat menyesuaikan pembelajaran dengan bakat dan minat serta kesiapan peserta didik. Kita ketahui peserta didik mempunyai perbedaan individual namun dengan belajar dalam kelompok kecil yang heterogen mereka dapat saling berkolaborasi satu sama lainnya dengan kemampuan yang sama. Pembelajaran Teams Games Tournament ini dapat meningkatkan motivasi, membangkitkan minat dan kreatifitas belajar Matematika.

\section{METODE}

Bentuk penelitian yang dilaksanakan adalah Penelitian Tindakan Kelas (PTK). Penelitian tindakan kelas merupakan terjemahan dari Classroom Action Research yaitu action research yang dilakukan di dalam kelas, dimana action research diartikan sebagai penelitian tindakan. Arikunto, dkk (2012:3) menyatakan bahwa "penelitian tindakan kelas merupakan suatu pencermatan terhadap kegiatan belajar berupa sebuah tindakan, yang sengaja dimunculkan dan terjadi dalam sebuah kelas secara bersama".

Penelitian ini dilaksanakan di SMP Negeri 2 Pangkalan Kerinci yang berlokasi di jalan Hang Tuah desa Makmur Kecamatan Pangkalan Kerinci Kabupaten Pelalawan. Penelitian dilakukan pada semester genap di kelas $\mathrm{VII}_{\mathrm{B}}$ SMP Negeri 2 Pangkalan Kerinci tahun pelajaran 2016/2017 yang berjumlah 28 orang dengan peserta didik laki-laki sebanyak 13 orang dan peserta didik perempuan sebanyak 15 orang. Kompetensi dasar pada saat penelitian adalah Menghitung Luas dan Keliling Segiempat.

Penelitian ini dilaksanakan melalui empat langkah utama yaitu perencanaan, tindakan, observasi, dan refleksi.

Tahap 1. Menyusun Rencana Tindakan (Planning) Kegiatan yang dilaksanakan pada tahap perencanaan adalah :

1. Menyusun Silabus

2. Menyusun RPP

3. Menyusun lembar pengamatan siswa dan lembar pengamatan guru

4. Membuat Lembar Kerja Peserta Didik (LKPD)

5. Membentuk kelompok yang beranggota 4-5 orang

6. Membuat lembaran peraturan permainan

7. Menyiapkan lembaran jawaban

8. Menyiapkan beberapa set kartu soal

9. Menyiapkan lembaran pencatat skor permainan

10. Menyiapkan beberapa set kunci jawaban.

\section{Tahap 2. Pelaksanaan Tindakan (Acting)}

Pada siklus I kegiatan dilaksanakan pada tahap pelaksanaan tindakan adalah melaksanakan dua kali pertemuan, yakni :

1. Pertemuan 1: menyajikan materi ajar Memahami Jenis dan Sifat Bangun Persegi dan Persegi panjang yakni pada tanggal 22 Maret 2017 (waktu 2x40 menit). 
2. Pertemuan 2: menyajikan materi ajar Memahami Keliling dan Luas Bangun Persegi dan Persegi Panjang yakni pada tanggal 24 Maret 2017 (waktu 3x40 menit).

Pada siklus II kegiatan dilaksanakan pada tahap pelaksanaan tindakan adalah melaksanakan dua kali pertemuan, yakni :

1. Pertemuan 1: menyajikan materi ajar Memahami Jenis dan Sifat Bangun Jajargenjang dan Belah Ketupat yakni pada tanggal 24 Maret 2017 (waktu 2x40 menit).

2. Pertemuan 2: menyajikan materi ajar Memahami Keliling dan Luas Bangun Jajargenjang dan Belah Ketupat yakni pada tanggal 31 Maret 2017 (waktu $3 \times 40$ menit).

Pada siklus III kegiatan dilaksanakan pada tahap pelaksanaan tindakan adalah melaksanakan dua kali pertemuan, yakni :

1. Pertemuan 1: menyajikan materi ajar Memahami Jenis dan Sifat Bangun Layang-layang dan Trapesium yakni pada tanggal 5 April 2017 (waktu 2x40 menit).

2. Pertemuan 2: menyajikan materi ajar Memahami Keliling dan Luas Bangun Layang-layang dan Trapesium yakni pada tanggal 7 April 2017 (waktu $3 \times 40$ menit).

\section{Tahap 3. Pengamatan (Observasi)}

Kegiatan yang dilaksanakan pada tahap observasi adalah melakukan observasi serta mencatat segala sesuatu yang terjadi pada saat pelaksanaan tindakan dengan menggunakan lembar pengamatan.

1. Mengamati aktivitas peserta didik terhadap pembelajaran.

2. Mengamati aktivitas guru dalam memberikan pelajaran.

\section{Tahap 4. Refleksi (Reflecting)}

Refleksi dilakukan untuk mengetahui kelebihan dan kekurangan pada pelaksanan pembelajaran. Data yang diperoleh dari kegiatan observasi siklus sebelumnya dianalisa dan dijadikan pedoman untuk melakukan tindakan pada siklus berikutnya. Kegiatan yang dilaksanakan pada kegiatan ini adalah:

1. Mendeskripsikan secara singkat kegiatan tindakan.

2. Mengevaluasi hasil observasi.

3. Menganalisa hasil pembelajaran.

4. Memperbaiki kelemahan.
Teknik yang digunakan dalam pengumpulan data adalah teknik pengamatan. Teknik ini digunakan untuk memperoleh data tentang aktivitas peserta didik dan guru selama proses pembelajaran dikumpulkan dengan cara melakukan pengamatan kelas oleh pengamat. Dalam mengumpulkan data ini, pengamat bertugas mengamati aktivitas peserta didik dan aktivitas guru sesuai dengan tuntutan RPP yang tersedia dalam lembar pengamatan.

Data diolah dan dirumuskan dengan menggunakan rumus :

$P=\frac{F}{N} x 100 \%$

Keterangan :

$\mathrm{P}=$ Angka Persentase

$\mathrm{F}=$ Frekuensi Aktivitas Belajar

$\mathrm{N}=$ Jumlah Siswa

Untuk memudahkan analisis data dan untuk mengetahui aktivitas siswa maka diberikan nilai atas observasi tersebut sesuai dengan kategori penilaian sebagai berikut :

Tabel 2: Interval dan Kategori Minat Belajar Siswa

\begin{tabular}{cc}
\hline Interval (\%) & Kategori \\
\hline $86-100$ & Amat Baik \\
$71-85$ & Baik \\
$56-70$ & Cukup \\
$\leq 55$ & Kurang \\
\hline
\end{tabular}

Sumber : Depdiknas (2007)

Aktivitas guru meliputi: Kegiatan Pendahuluan, Kegiatan Inti dan Kegiatan Penutup. Aktivitas guru dalam proses pembelajaran dengan rumus sebagai berikut:

$\boldsymbol{P}=\frac{\sum X}{N} \times 100 \%$ Sujiono (1997)

Keterangan:

$\mathrm{P} \quad=$ Persentase aktivitas guru

$\sum X=$ Jumlah frekuensi aktivitas guru

$\mathrm{N}=$ Jumlah indikator berikut:

Adapun kategori untuk aktivitas guru sebagai

Tabel 3: Interval dan Kategori Aktivitas Guru

\begin{tabular}{cc}
\hline Interval (\%) & Kategori \\
\hline $91-100$ & Amat Baik \\
$81-90$ & Baik \\
$70-80$ & Cukup \\
$<70$ & Kurang \\
\hline Sumber : Modifikasi BSNP (2006)
\end{tabular}




\section{HASIL DAN PEMBAHASAN}

Tabel 4: Perbandingan Persentase Minat Belajar Siswa pada Siklus I, Siklus II, dan Siklus III

\begin{tabular}{|c|c|c|c|c|c|c|c|}
\hline \multirow{2}{*}{ No } & \multirow{2}{*}{ Skala Nilai } & \multicolumn{3}{|c|}{ Jumlah Siswa } & \multicolumn{3}{|c|}{$\begin{array}{c}\text { Persentase Minat } \\
\text { Belajar }\end{array}$} \\
\hline & & $\begin{array}{c}\text { Siklus } \\
\text { I }\end{array}$ & $\begin{array}{c}\text { Siklus } \\
\text { II }\end{array}$ & $\begin{array}{l}\text { Siklus } \\
\text { III }\end{array}$ & $\begin{array}{c}\text { Siklus } \\
\text { I }\end{array}$ & $\begin{array}{c}\text { Siklu } \\
\text { sII }\end{array}$ & $\begin{array}{c}\text { Siklus } \\
\text { III }\end{array}$ \\
\hline 1 & $\begin{array}{l}\text { Melakukan } \\
\text { literasi } \\
\text { Matematika }\end{array}$ & 17 & 21 & 23 & $\begin{array}{l}60,71 \\
\%\end{array}$ & $\begin{array}{l}75,0 \\
0 \%\end{array}$ & $\begin{array}{l}82,14 \\
\%\end{array}$ \\
\hline 2 & $\begin{array}{l}\text { Serius } \\
\text { menyelesaikan } \\
\text { LKPD }\end{array}$ & 16 & 22 & 26 & $\begin{array}{l}57,14 \\
\%\end{array}$ & $\begin{array}{l}78,5 \\
\%\end{array}$ & $\begin{array}{l}92,85 \\
\%\end{array}$ \\
\hline 3 & $\begin{array}{l}\text { Bertanya } \\
\text { menjawab } \\
\text { pertanyaan tim }\end{array}$ & 20 & 24 & 25 & $\begin{array}{l}71,43 \\
\%\end{array}$ & $\begin{array}{l}85,7 \\
1 \%\end{array}$ & $\begin{array}{l}89,29 \\
\%\end{array}$ \\
\hline 4 & $\begin{array}{l}\text { Antusias } \\
\text { mengikuti } \\
\text { permainan }\end{array}$ & 15 & 24 & 24 & $\begin{array}{l}53,57 \\
\%\end{array}$ & $\begin{array}{l}85,7 \\
1 \%\end{array}$ & $\begin{array}{l}85,71 \\
\%\end{array}$ \\
\hline \multicolumn{5}{|c|}{ Rata-rata } & $\begin{array}{l}60,71 \\
\%\end{array}$ & $\begin{array}{l}81,2 \\
4 \%\end{array}$ & $\begin{array}{l}87,49 \\
\%\end{array}$ \\
\hline
\end{tabular}

Dari tabel di atas. pada siklus I masih banyak terdapat kekurangan-kekurangan. Pada aspek melakukan literasi matematika, serius dalam menyelesaikan LKPD, bertanya dan menjawab pertanyaan tim, dan antusias dalam mengikuti permainan masih dalam kategori $\mathrm{C}$ (cukup). Hal ini disebabkan karena peserta didik belum terbiasa dengan proses pembelajaran yang diterapkan, yaitu Team Games Tournament (TGT), sehingga pelaksanaan proses pembelajaran masih ragu-ragu dan suasana kelas menjadi tegang. Namun, dengan adanya pembagian kelompok yang heterogen sehingga peserta didik dapat bertanya mengenai hal yang belum dipahami kepada teman sekelompoknya.

Pada siklus II rata-rata minat siswa lebih baik daripada siklus sebelumnya. Pada aspek melakukan literasi matematika $75,00 \%$, serius dalam menyelesaikan LKPD 78,57\%, bertanya dan menjawab pertanyaan tim, dan antusias dalam mengikuti pembelajaran $85,71 \%$ sehingga dapat dikategorikan dalam kategori B (baik). Begitupun dalam penerapan pembelajaran Pembelajaran Teams Games Tournament ini sudah menunjukkan peningkatan dibandingkan dengan siklus I. Hal ini dapat dilihat dari proses pembelajaran yang dilakukan, terlihat adanya guru sudah membimbing siswa yang belum menguasai materi pelajaran. Guru juga memotivasi siswa untuk melakukan literasi matematika dengan menemukan sendiri rumus matematikanya, sehingga pengetahuan itu bertahan lama dalam dirinya.

Pada siklus III penerapan pembelajaran Pembelajaran Teams Games Tournament ini sudah sesuai dengan yang diharapkan karena proses pembelajaran pada siklus III sudah lebih baik dibandingkan dengan siklus sebelumnya. Hal ini dapat dilihat dari minat belajar siswa dan aktivitas guru dalam melakukan pembelajaran. Pada aspek melakukan literasi matematika $82,14 \%$, serius dalam menyelesaikan LKPD 92,85\%, bertanya dan menjawab pertanyaan tim $89,29 \%$, dan antusias dalam mengikuti pembelajaran $85,71 \%$ sehingga dapat dikategorikan dalam kategori A (amat baik). Adanya bimbingan guru membuat siswa tidak malu untuk bertanya mengenai hal yang belum dipahami.

Berdasarkan data Rekapitulasi Hasil Observasi Aktivitas Guru oleh observer selama proses pembelajaran dapat dilihat pada tabel berikut.

Tabel 5. Hasil Aktivitas Guru dengan Model Pembelajaran Teams Games Tournament di Kelas $\mathrm{VII}_{\mathrm{B}}$ SMP Negeri 2 Pangkalan Kerinci

\begin{tabular}{|l|l|l|}
\hline \multicolumn{1}{|c|}{ Siklus } & \multicolumn{1}{c|}{$\begin{array}{c}\text { Persentase } \\
\text { Aktivitas Guru }\end{array}$} & Kategori \\
\hline Rata-rata persentase siklus I & $68,75 \%$ & Cukup \\
\hline Rata-rata persentase siklus II & $81,25 \%$ & Baik \\
\hline $\begin{array}{l}\text { Rata-rata persentase siklus } \\
\text { III }\end{array}$ & $100 \%$ & $\begin{array}{l}\text { Amat } \\
\text { Baik }\end{array}$ \\
\hline
\end{tabular}

Dari tabel di atas dapat dilihat bahwa aktivitas guru mulai dari siklus I sampai siklus II terdapat peningkatan dari kategori cukup menjadi kategori baik. Guru sudah melaksanakan beberapa proses pembelajaran Teams Games Tournament. Tugas penting bagi guru dalam menerapkan model pembelajaran ini adalah memberi motivasi agar siswa berminat mengikuti pembelajaran matematika. Pada siklus II dan siklus III juga terjadi peningkatan kategori dari baik menjadi amat baik sehingga semua langkahlangkah pembelajaran yang dilaksanakan sudah sesuai dengan rencana pembelajaran.

Hasil tindakan yang dianalisis yaitu kegiatan pembelajaran pada siklus I yang dapat dilihat pada lembar pengamatan aktivitas guru dan lembar pengamatan minat belajar siswa. Aktivitas guru masih banyak yang belum sesuai dengan RPP sehingga proses pembelajaran belum maksimal. Selanjutnya diharapkan guru mampu mengamati siswa yang mengalami kesulitan belajar dan membimbing peserta didik agar lebih baik lagi dalam melaksanakan aktivitasnya, sehingga mereka berminat dalam mengikuti pembelajaran.

Begitu juga dengan siswa masih ada yang belum melakukan kegiatan literasi untuk menemukan jawaban LKPD. Ada peserta didik yang hanya menunggu jawaban dari teman yang mampu tanpa berfikir untuk berusaha mendapatkan jawabannya sehingga waktu banyak terpakai dalam mengerjakan LKPD. Untuk selanjutnya guru harus meningkatkan usahanya dalam memperhatikan langkah-langkah pembelajaran dan 
membimbing peserta didik agar serius menyelesaikan LKPD dan bekerja sama dengan kelompoknya.

Berdasarkan hasil pengamatan selama melakukan tindakan siklus I, pelaksanaan cukup baik sesuai dengan perencanaan pembelajaran, namun hanya sebatas cukup baik. Aktivitas guru dan peserta didik belum berjalan dengan baik, kekurangan tersebut dapat dilihat dalam berbagai hal seperti guru belum dapat melaksanakan semua kegiatan yang sudah direncanakan, guru belum dapat memfasilitasi peserta didik. Hal ini disebabkan karena belum terbiasa sehingga strategi yang diterapkan belum berjalan seperti yang diharapkan dan masih banyak kekurangan yang terjadi.

Setelah berdiskusi dengan observer maka perbaikan proses pembelajaran yang akan dilakukan adalah:

1. Guru akan meningkatkan usahanya dalam pelaksanaan kegiatan pembelajaran agar lebih baik lagi dengan lebih memotivasi peserta didik pada saat literasi matematika.

2. Guru harus lebih siap dengan alat peraga agar peserta didik dapat menemukan jawaban pertanyaan dengan baik.

3. Guru harus bisa menggunakan waktu dengan tepat sesuai dengan perencanaan.

4. Pada saat mengerjakan LKPD berlangsung, guru akan lebih mengontrol kegiatan yang dilakukan oleh peserta didik agar tidak ada lagi peserta didik yang hanya mengharapkan jawaban dari teman kelompoknya.

Hasil perbaikan pada siklus II, sudah terlihat peningkatan pada proses pembelajaran. Guru sudah menyampaikan tujuan pembelajaran dan memotivasi peserta didik agar bekerjasama dalam kelompoknya. Langkah-langkah pembelajaran yang diamati juga sudah terlaksana dengan baik.

Pada kegiatan penyajian kelas guru mengarahkan siswa untuk melaksanakan literasi matematika agar siswa menemukan sendiri cara menyelesaikan permasalahan. Kemudian guru menyerahkan LKPD kepada setiap kelompok. Terlihat siswa sudah mulai melakukan kegiatan literasi dengan cara membaca buku sumber atau melakukan browsing di internet. Guru memfasilitasi siswa yang kurang paham dengan maksud pertanyaan di LKPD. Sudah ada keseriusan siswa dalam menyelesaikan LKPD.

Pada permainan akademik, sudah tampak antusias siswa dalam mengikuti permainan. Setelah permainan selesai, ditentukan pemenang dan diberikan penghargaan kelompok. Pada akhir siklus II peserta didik menanyakan cara membedakan rumus. Guru memberikan penjelasan sehingga siswa merasa sangat puas dengan model pembelajaran ini.

Berdasarkan hasil pengamatan yang berpedoman pada lembar pengamatan aktivitas guru terlihat aktivitas guru dalam menerapkan model pembelajara ini hampir sempurna, semua aktivitas yang ada di RPP dilaksanakan oleh guru. Sedangkan pengamatan untuk minat belajar siswa juga sudah meningkat. Peserta didik sudah dapat lebih tertib dalam mengikuti pembelajaran yang dilakukan, artinya secara umum peserta didik sudah melaksanakan aktivitasnya dengan lebih baik lagi dibandingkan pada siklus sebelumnya.

Hasil analisis data pada siklus III, proses pembelajaran sudah dilakukan dengan sangat baik. Pada lembar pengamatan guru langkah-langkah yang diamati sudah terlaksana sesuai dengan yang diharapkan. Pada kegiatan penyajian kelas guru mengarahkan siswa untuk memperhatikan tayangan multimedia. Kemudian guru menyerahkan LKPD kepada setiap kelompok. Siswa sudah mulai berdiskusi dengan tertib dan semangat. Guru memancing siswa yang kurang paham untuk bertanya dan siswa yang sudah mengerti diminta untuk menjawab pertanyaan temannya. Siswa kembali serius menyelesaikan LKPD setelah tanya jawab selesai.

Pada permainan akademik, siswa sangat antusias dalam mengikuti permainan. Setelah permainan selesai, ditentukan pemenang dan diberikan penghargaan kelompok. Siswa terlihat sangat puas dengan model pembelajaran ini. Secara keseluruhan jika dibandingkan dengan siklus sebelumnya proses pembelajaran pada siklus III ini sudah jauh lebih baik.

Dengan demikian penerapan pembelajaran kooperatif tipe Teams Games Tournament (TGT) dapat membantu peserta didik untuk berkolaborasi dalam kelompoknya, serta dengan mudah peserta didik mengingat apa yang telah dipelajari karena dalam proses pembelajaran peserta didik yang berperan aktif dalam menemukan teori atau rumus dari pelajaran tersebut, sehingga dapat memberikan dampak positif terhadap minat belajar peserta didik. Pada pertemuan berikutnya diharapkan guru dapat menerapkannya karena peserta didik sudah mulai terbiasa dengan pembelajaran yang diterapkan.

Berdasarkan uraian di atas dapat diketahui bahwa aktivitas guru dan peserta didik dengan penerapan pembelajaran kooperatif tipe Teams Games Tournament (TGT) pada siklus II mengalami peningkatan dari siklus I, dan siklus III mengalami peningkatan dari siklus II, dimana pada siklus III aktivitas guru dan peserta didik sudah dilaksanakan sesuai rencana pelaksanaan pembelajaran dengan baik. 
Hasil penelitian pada tindakan kelas diperoleh kesepakatan bahwa dengan penerapan model pembelajaran Teams Games Tournament dapat meningkatkan minat belajar siswa.

Secara keseluruhan hasil penelitian ini telah dapat meningkatkan minat belajar siswa. Disadari sepenuhnva bahwa peningkatan ini terjadi secara bertahap sesuai dengan kemampuan guru dan siswa. Sehingga dapat disimpulkan terdapat peningkatan minat belajar siswa dengan penerapan pembelajaran Teams Games Tournament (TGT). Jadi, hasil analisis tindakan ini mendukung hipotesis tindakan yang diajukan yaitu penerapan Pembelajaran Teams Games Tournament dapat meningkatkan minat belajar Matematika peserta didik kelas $\mathrm{VII}_{\mathrm{B}}$ SMP Negeri 2 Pangkalan Kerinci tahun pelajaran 2016/2017.

\section{SIMPULAN}

Berdasarkan hasil penelitian yang telah dilaksanakan dalam tiga siklus dan pembahasan pada BAB IV maka dapat disimpulkan bahwa penerapan pembelajaran Teams Games Tournament (TGT) dapat meningkatkan minat belajar Matematika peserta didik kelas $\mathrm{VII}_{\mathrm{B}}$ SMP Negeri 2 Pangkalan Kerinci tahun pelajaran 2016/2017 pada KD Menghitung Luas dan Keliling Segiempat. Hal ini dapat dilihat dari persentase minat belajar siswa sudah meningkat dan soal-soal yang diberikan guru bisa dikerjakan.

Melalui tulisan ini peneliti memberikan beberapa saran yang berhubungan dengan penerapan pembelajaran Pembelajaran Teams Games Tournament, yaitu sebagai berikut:

1) Sekolah diharapkan dapat menjadikan penerapan pembelajaran Teams Games Tournament ini menjadi salah satu strategi pembelajaran yang diterapkan dalam proses pembelajaran di sekolah.

2) Guru matematika sebaiknya menjadikan penerapan pembelajaran Teams Games Tournament (TGT) ini sebagai salah satu cara untuk meningkatkan minat belajar peserta didik.

\section{DAFTAR PUSTAKA}

Arikunto, S., Suhardjono, dan Supardi. (2012). Penelitian Tindakan Kelas. Jakarta: Bumi Aksara.

Badan Standar Nasional Pendidikan. (2006). Panduan Penyusunan Kurikulum Tingkat Satuan Pendidikan Dasar dan Menengah. Jakarta: Depdiknas.

Daryanto. (2012). Model Pembelajaran Inovatif. Yogyakarta: penerbit Gava Media

Fathurrohman, M. (2015). Paradigma Pembelajaran Kurikulum 2013: Strategi Alternatif Pembelajaran di Era Global. Yogyakarta: Kalimedia.

Lucy, B. (2009). Mendidik Sesuai dengan Minat dan Bakat Anak (Patenting Your Children's Future). Jakarta: Tangga Pustaka.

Marno.. (2014). Strategi, Metode, dan Teknik Mengajar: Menciptakan Keterampilan Mengajar secara Efektif dan Edukatif. Yogyakarta: Ar-Ruzz Media.

Supriyadi. (2015). Strategi Belajar Mengajar. Yogyakarta: Cakrawala Ilmu

Sujiono, A. (2009). Pengantar Evaluasi Pendidikan. Jakarta: Rajawali Persada.

Depdiknas. 2007. Laporan Penilaian Hasil Belajar Siswa Sekolah Menengah Pertama (SMP). Jakarta. 